\title{
APPLICABILITY OF FORECASTED BANKRUPTCY MODELS TO RUSSIAN INDUSTRIAL COMPANIES
}

\author{
G.S. Chebotareva ${ }^{1}$, W. Strielkowski ${ }^{2}$, N.S. Gafurov ${ }^{3}$ \\ ${ }^{1}$ Ural Federal University, Ekaterinburg, Russian Federation \\ ${ }^{2}$ Czech University of Life Sciences, Prague, Czech Republic \\ ${ }^{3}$ South Ural State University, Chelyabinsk, Russian Federation \\ E-mails: g.s.chebotareva@urfu.ru, strielkowski@pef.czu.cz, gafurovns@susu.ru
}

\begin{abstract}
The application of effective methods for forecasting of the bankruptcy of industrial companies is always an urgent task for businesses, especially at the present stage which is characterized by an extremely high uncertainty. The paper presents the main techniques of bankruptcy modelling used in the world's practice: logit, probit and MDA-models, as well as the special private methods developed on their basis. These tools constitute the methodological foundation of our research. To assess the practical applicability of these methods to the contemporary Russian market, two sectorial companies (bankrupt and nonbankrupt) are selected as the object of study. A feature of the research is the use of financial statements of companies developed according to Russian and international standards. In the course of the calculations, we apply external and internal restrictions related to the key rate, credit history characteristics, age and regional affiliation of companies. Based on the dynamic assessment, we draw conclusions about the practical applicability and inapplicability of certain forecast models for the Russian economy. We investigate the relationship between the assessment results and the type of source data used. Research veracity is confirmed using generally recognized models and methods, as well as the practical implementation of the results obtained. We can recommend to use these results for improving the existing models for predicting bankruptcy and developing new ones, as well as for owners and investors of companies who need to make strategic decisions.
\end{abstract}

Keywords: bankruptcy; forecast; industrial company; mathematical modelling; logit model; probit model; MDA-model; Russian market.

\section{Introduction}

Modern practice of forecasting bankruptcy of sectorial companies is based on the evaluation of mathematical models that substantially differ according to financial statements and indicators. The set of such models can be divided into three large groups: logit, probit, and MDA-models, each of which has its own specifics [1-4]. However, in today's rapidly changing market conditions and unstable political environment, the issue of the practical significance of such models for accurate and objective assessment of the risk of bankruptcy becomes more acute. This problem is enormously essential not only for the companies themselves, but also for their investors. Hence, the challenge of applicability of such forecasted models for the Russian companies is very relevant both from the scientific and practical points of view. The decision problem involves two main stages.

\section{Methodology for Modelling Bankruptcy of Sectorial Companies}

In general form, logit models are given by the logistic regression equation (1) [1]:

$$
P B=\frac{1}{1+e^{Y}}
$$


where $P B$ is a probability of company bankruptcy in accordance with condition $(2)$; $e$ is Euler number $(e \approx 2,71828) ; Y$ is an individual integral indicator.

$$
P B=\left\{\begin{array}{l}
\text { from } 0 \text { when value of } \mathrm{PD} \text { of energy company is minimum, } \\
\text { to } 1 \text { when value of } \mathrm{PD} \text { is maximum. }
\end{array}\right.
$$

The integral indicator $Y$ is evaluated by the specific model

$$
Y=b_{0}+b_{1} \cdot X_{1}+b_{2} \cdot X_{2}+\ldots+b_{n} \cdot X_{n}
$$

where $X_{j}$ is the $j$-th financial indicator; $b_{j}$ is the evaluation value of the $j$-th coefficient' significance; $j \in[1 ; n]$.

In the empirical part of this paper, we consider five most common logit models: Chesser, Khaidarshina, Zhdanov, Joo-Ha-Taehong and Altman-Sabato [2]. For instance, the integral indicator of the Chesser logit model is briefly described as

$$
Y=-2,04-5,2 \cdot X_{1}+0,01 \cdot X_{2}-6,7 \cdot X_{3}+4,4 \cdot X_{4}-0,08 \cdot X_{5}-0,1 \cdot X_{6},
$$

where $X_{1}$ is the ratio of cash and market securities to the total assets; $X_{2}$ is the ratio of profit on sales to the amount of cash and market securities; $X_{3}$ is the ratio of earnings before interest and taxes to the total assets; $X_{4}$ is the ratio of total liabilities to total assets; $X_{5}$ is the ratio of fixed capital to equity capital; $X_{6}$ is the ratio of current assets to profit on sales.

In addition, the integral indicator of Khaydarshina logit model, calculated for industrial enterprises, assumes qualitative and quantitative assessment given by

$$
\begin{aligned}
& Y=-10,21-0,03 \cdot K_{1}-6,75 \cdot K_{2}+3,71 \cdot K_{3}+1,6 \cdot K_{4}+0,56 \cdot K_{5}+ \\
& +0,13 \cdot K_{6}+1,37 \cdot K_{7}+6,36 \cdot K_{8}+0,28 \cdot K_{9}-2,6 \cdot K_{10}+7,31 \cdot K_{11},
\end{aligned}
$$

where $K_{1}$ takes into account the factor of the company "age" $(6) ; K_{2}$ is the characteristics of the company's credit history $(7) ; K_{3}$ is the current ratio; $K_{4}$ is the ratio of earnings before interest and taxes to interest paid; $K_{5}$ is the weighted average capital of the company; $K_{6}$ is average key rate of the Bank of Russia; $K_{7}$ is the regional affiliation of the company (8); $K_{8}$ is Return on Assets; $K_{9}$ is Return on Equity; $K_{10}$ is the growth rate of the equity capital; $K_{11}$ is the growth rate of assets.

$$
\begin{gathered}
K_{1}=\left\{\begin{array}{l}
0, \text { if the company was created more than } 10 \text { years ago } \\
1, \text { if the company was created less than } 10 \text { years ago, }
\end{array}\right. \\
K_{2}= \begin{cases}0, & \text { if the company has positive credit history, } \\
1, & \text { if the company has negative credit history, }\end{cases} \\
K_{7}=\left\{\begin{array}{l}
0, \text { if the company is located in Moscow or Saint-Petersburg, } \\
1, \text { if the company is located in another city. }
\end{array}\right.
\end{gathered}
$$

Probit models are based on normal data distribution and binary probability value and can be given in the general form as follows:

$$
P B=f(Z),
$$


where $P B$ is the probability of company bankruptcy in accordance with condition (10); $f$ is the function of standard normal distribution; $Z$ is the individual integral indicator.

$$
P B=\left\{\begin{array}{l}
\text { from } 0 \text { if the company is bankrupt } \\
\text { to } 1 \text { if the company is non-bankrupt. }
\end{array}\right.
$$

The practical absence of normal data distribution at the present stage made the use of probit models less frequent. However, in the practical part, the Zmijewski model [3] is considered:

$$
P B=f\left(-4,3-4,5 \cdot X_{1}+5,7 \cdot X_{2}+0,004 \cdot X_{3}\right),
$$

where $X_{1}$ is the ratio of net profit to total assets; $X_{2}$ is the ratio of total liabilities to total assets; $X_{3}$ is the ratio of current assets to short-term liabilities.

The general form of multiple discriminant analysis (MDA) models is presented in (12). The interpretation of each MDA-model is individual and can vary beyond the range from 0 to 1

$$
Z=a+b \cdot K_{1}+c \cdot K_{2}+d \cdot K_{3}+\ldots+n \cdot K_{n}
$$

where $Z$ is the final indicator of the MDA-model that characterizes the probability of company bankruptcy; $a, b, c, d, \ldots, n$ are the regression coefficients; $K_{1}, K_{2}, K_{3}, \ldots, K_{n}$ are the independent variables.

We analyzed ten foreign and domestic MDA-models in the context of the research problem [2-5]: three Altman models, as well as models of Lis, Springate, Taffler, Fulmer, Fedotova, Savitskaya and Belikov-Davydova [1, 2].

\section{Assessing the Practical Applicability of Bankruptcy Models to Russian Industrial Companies}

Two functioning Russian companies are selected as objects and conventionally denoted by "A" and " $\mathrm{B}$ ". Moreover, company " $\mathrm{A}$ " is currently successfully operating in its market and does not fall into the bankruptcy zone during the study period; company "B" was declared bankrupt several years ago, and the information for analysis on it was taken for that period. Forecasting of the bankruptcy of these companies using models above allow to assess the current applicability of these models for the Russian market.

Both five-factor models of Altman, as well as models of Khaidarshina, Lis, Taffler, Springate, Savitskaya, Belikov-Davydova and Zmijewski showed absolutely accurate results about the state of companies. The models of Joo-Ha-Taehong, Altman-Sabato and Fedotova confirmed success of the company "A". The Chesser's logit model confirmed bankruptcy of the company "B" in the case of IFRS. The model of Zhdanov showed incorrect results for the company "A" in the case of IFRS. The two-factor models of Altman and Fulmer gave an error when evaluating the company "B" according to RAS data.

\section{Conclusions}

1. All in all, we solved the actual problem of assessing the applicability of existing forecasted bankruptcy models for the Russian market. 
2. In addition, we studied the relationship between the assessment results and the types of models used, as well as the source data (RAS and IFRS).

3. Moreover, we recommend to use our results in the development of new models for forecasting of the bankruptcy of sectorial companies.

Acknowledgements. The work was supported by Act 211 of the Government of the Russian Federation (contract no. 02.A03.21.0006) and GSEM UrFU Development Fund.

The authors are grateful to Doctor of Economics, Professor V. Mokhov for many years and fruitful cooperation and congratulate him on his anniversary.

\section{References}

1. Mokhov V.G., Chebotareva G.S. Research of Default Risk Level of Russian Energy. Bulletin of the South Ural State University. Series: Mathematical Modelling, Programming and Computer Software, 2018, vol. 12, no. 2, pp. 166-171. DOI: 10.14529/mmp190215

2. Muradov D.A. [Logit-Regression Models for Predicting Enterprise Bankruptcy]. Proceedings of the Gubkin Russian State University of Oil and Gas, 2011, vol. 3 (264), pp. 160-172. (in Russian)

3. Kazakov A.V., Kolyshkin A.V. Development of Models for Forecasting Bankruptcy in Modern Russian Conditions. Bulletin of St. Petersburg University. Economy, 2018, vol. 34, no. 2, pp. 241-266. (in Russian) DOI: 10.21638/11701/spbu05.2018.203

4. Khaidarshina G.A. [Effectiveness of Modern Methods for Assessing the Risk of Bankruptcy of Enterprises in the Russian Practice of Financial Management: Logit and SVM Models]. Economic Science, 2008, vol. 44, pp. 300-304. (in Russian)

5. Dokukina A.A., Ivanova E.A. Forecasting the Bankruptcy of an Organization on the Basis of Its Financial Conditions Assessment. Human Capital and Professional Education, 2015, vol. 1, no. 13, pp. 35-47. (in Russian)

Received March 24, 2020

УДК 330.322.013+001.895

DOI: $10.14529 / \mathrm{mmp} 200311$

\section{ПРИМЕНИМОСТЬ ПРОГНОЗНЫХ МОДЕЛЕЙ БАНКРОТСТВА К РОССИЙСКИМ ОТРАСЛЕВЫМ КОМПАНИЯМ}

\section{Г.С. Чеботарева ${ }^{1}$, В. Стриелковски ${ }^{2}$, Н.ШІ. Гафуров ${ }^{3}$}

${ }^{1}$ Уральский федеральный университет им. первого Президента России

Б.Н. Ельцина, г. Екатеринбург, Российская Федерация

${ }^{2}$ Чешский аграрный университет, г. Прага, Чешская Республика

${ }^{3}$ Южно-Уральский государственный университет, г. Челябинск,

Российская Федерация

Использование эффективных методов прогнозирования банкротства отраслевых компаний всегда является актуальной для бизнеса задачей, особенно на современном этапе, характеризующемся чрезвычайно высокой неопределенностью. В статье представлены основные способы моделирования банкротства, используемые в мировой практике: logit, probit и $M D A$-модели, а также разработанные на их основе частные 
методы. Данный инструментарий является методологической базой проведенного исследования. Для оценки практической применимости данных подходов к современному российскому рынку в качестве объектов выбраны две отраслевые компании: банкрот и не банкрот. Особенностью проведенного исследования является использование финансовых данных компаний, разработанных по российским, а также международным стандартам. При проведении расчетов приняты внешние и внутренние ограничения, связанные с размером ключевой ставки, характеристикой кредитных историй, возрастом и региональной принадлежностью компаний. На основе проведенной динамической оценки сделаны выводы о практической применимости и неприменимости отдельных прогнозных моделей для российской экономики. Исследована зависимость между результатами оценки и типом используемых исходных данных. Достоверность полученных выводов подтверждена применением общепризнанных моделей и методов, а также практической реализацией полученных результатов. Данные результаты рекомендуется использовать при совершенствовании существующих и разработке новых моделей прогнозирования банкротства, а также собственникам и инвесторам компаний при принятии стратегических решений.

Ключевые слова: банкротство; прогнозирование; отраслевые компании; математическое моделирование; logit-модель; probit-модель; MDA-модель; российский рънок.

\section{Литература}

1. Mokhov, V.G. Research of Default Risk Level of Russian Energy / V.G. Mokhov, G.S. Chebotareva // Вестник ЮУрГУ. Серия: Математическое моделирование и программирование. - 2018. - Т. 12, № 2. - Р. 166-171.

2. Мурадов, Д.А. Logit-регрессионные модели прогнозирования банкротства предприятий / Д.А. Мурадов // Труды российского государственного университета нефти и газа имени И.М. Губкина. - 2011. - № 3 (264). - С. 160-172.

3. Казаков, А.В. Разработка моделей прогнозирования банкротства в современных российских условиях. / А.В. Казаков, А.В. Колышкин // Вестник Санкт-Петербургского университета. Экономика. - 2018. - Т. 34, № 2. - С. 241-266.

4. Хайдаршина, Г.А. Эффективность современных методов оценки риска банкротства предприятий в российской практике финансового менеджмента: logit- и SVM-модели / Г.А. Хайдаршина // Экономические науки. - 2008. - № 44. - С. 300-304.

5. Докунина, А.А. Прогнозирование банкротства организации на основе оценке финансового состояния / А.А. Докунина, Е.И. Иванова // Человеческий капитал и профессиональное образование. - 2015. - Т. 1, № 13. - С. 35-47.

Галина Сергеевна Чеботарева, кандидат экономических наук, доцент, кафедра «Банковский и инвестиционный менеджмент», Уральский федеральный университет им. первого Президента России Б.Н. Ельцина (г. Екатеринбург, Российская Федерация), g.s.chebotareva@urfu.ru.

Вадим Стриелковски, доктор экономических наук, профессор, кафедра «Торговля и финансы», факультет экономики и управления, Чешский аграрный университет (г. Прага, Чешская Республика), strielkowski@ppef.czu.cz.

Наиль Шайхрамович Гафуров, кандидат технических наук, доцент, кафедра «Прикладная экономика», Южно-Уральский государственный университет (г. Челябинск, Российская Федерация), gafurovns@susu.ru.

Поступила в редакиию 24 марта 2020 2. 